Chirurgia (2021) 116: 515-523

No. 5, September-October

Copyright $\odot$ Celsius

http://dx.doi.org/10.21614/chirurgia.116.5.515

\title{
Current Insights in the Pathophysiology of Gastroesophageal Reflux Disease
}

\author{
Karl-Hermann Fuchs ${ }^{1 *}$, Alexander Meining ${ }^{1,2}$ \\ ${ }^{1}$ Laboratory for Interventional and Experimental Endoscopy, University of Würzburg, 97080 Würzburg, Germany \\ ${ }^{2}$ University of Würzburg, Zentrum Innere Medizin, Head of Gastroenterology, 97080 Würzburg, Germany
}

${ }^{*}$ Corresponding author:

Prof. Dr. med. Karl-Hermann Fuchs

Senior Professor

Laboratory for Interventional and

Experimental Endoscopy, University of Würzburg Gastroenterology

Grombühlstr, 12, 97080 Würzburg

Germany

E-mail: Karl-Hermann.Fuchs@gmx.de

Abbreviations:

GERD - gastroesophageal reflux disease,

LES - lower esophageal sphincter,

EAE - esophageal acid exposure,

HRM - High Resolution Manometry,

\section{Rezumat}

Perspective actuale asupra fiziopatologiei bolii de reflux gastroesofagian

Fiziopatologia bolii de reflux gastroesofagian (BRGE) este determinată multifactorial şi rămâne un subiect de dezbatere între specialitățile medicale implicate, în special între gastroenterologi şi chirurgi gastro-intestinali, dar şi medici ORL şi pneumologi. Scopul acestui studiu este de a oferi o privire de ansamblu asupra influenței diferitelor componente fiziopatologice ale BRGE, precum şi de a evalua gradul implicării lor în boală. Sfincterul esofagian inferior (SEI) asigură împreună cu muşchii şi structurile ligamentare ale diafragmei bariera antireflux dintre esofag şi stomac. Factorul crucial în BRGE îl reprezintă refluxul unei cantități importante de conținut gastric în esofag. Acest lucru determină expunerea patologică a mucoasei esofagiene la aciditatea gastrică, cu apariția leziunilor şi simptomelor. Mecanismele fiziopatologice care stau la bază implică structuri anatomice, precum SEI şi diafragma, şi componente funcționale, precum incompetența SEI, relaxarea tranzitorie a SEI, afectarea motilității esofagiene, disfuncții gastroduodenale şi apariția refluxului duodeno-gastroesofagian. Evaluarea cantitativă a acestor componente a fost raportată într-o serie de studii care demonstrează importanța incompetenței SEI (incidență> 80\%) şi rolul herniei hiatale (incidență> 80\%) în severitatea BRGE indicată de expunerea excesivă a esofagului la acid şi de leziunile macroscopice ale mucoasei esofagiene. Toate componentele fiziopatologice cunoscute ale BRGE pot fi investigate în prezent prin teste diagnostice care identifică incompetența SEI sau creşterea relaxării tranzitorii, 
prezența herniei hiatale cu dimensiuni crescute, expunerea crescută a esofagului la conținutul gastric. In plus, pot fi asociate alte tulburări funcționale precum alterarea motilitătii esofagiene sau evacuare gastrică întârziată, care pot contribui la agravarea bolii şi a stării pacientului.

Cuvinte cheie: BRGE, fiziopatologie BRGE, sfincter esofagian inferior, hernie hiatală

\begin{abstract}
The pathophysiology of Gastroesophageal reflux disease (GERD) is multifactorial determined and remains a matter of discussions between the involved medical subspecialties, mainly gastroenterologists and gastrointestinal surgeons, but also ear-nose-and-throat colleagues and pulmonologists. The purpose of this manuscript is an overview on the different pathophysiologic components of GERD, their influence as well as a certain weighing of their involvement in the disease. The lower esophageal sphincter (LES) represents together with the muscles and ligamentous structures of the diaphragm at the esophageal hiatus the antireflux barrier between esophagus and stomach. The crucial factor in GERD is an increased amount of gastric contents refluxing into the esophagus above the physiologic level. This creates pathologic esophageal acid exposure (EAE) to the mucosa, which may lead to symptoms and damage. The underlying pathophysiologic mechanisms are anatomical components such as LES and diaphragm, and functional components such as LES-incompetence, transient LES relaxations, impaired esophageal motility, gastroduodenal dysfunctions and alterations of the refluxate such as duodeno-gastro-esophageal reflux. The quantitative assessment of these components has been reported in a number of studies demonstrating the importance of LES-incompetence (incidence $>80 \%$ ) and the role of hiatal hernia (incidence $>80 \%$ ) in the severity of GERD indicated by excessive esophageal acid exposure and visible damage of the esophageal mucosa. All known pathophysiologic components of GERD can be investigated currently by diagnostic assessment, detecting a LES-incompetence or an increase in transient relaxations, detecting a hiatal hernia with increasing size, detecting increasing exposure to gastric contents in addition to other possible functional associated disorders such as an insufficient esophageal motility and or a delayed gastric emptying, which all can aggravate the disease and the patient's status.
\end{abstract}

Key words: GERD, GERD-pathophysiology, lower esophageal sphincter, hiatal hernia

\section{Introduction}

The pathophysiology of Gastroesophageal reflux disease (GERD) remains a matter of discussions between the involved medical subspecialties, mainly gastroenterologists and gastrointestinal surgeons, but also ear-noseand-throat colleagues and pulmonologists (1-4). This originates from the large spectrum of presenting symptoms of this disease, which causes patients to seek help in different areas of medicine (2,5-8). The Montréal classification for GERD is accepted around the world, providing some insight into the pathophysiologic background of the disease and providing a definition of GERD using symptoms (2). The draw-back of a symptom-based definition is the weakness of precision and specificity regarding symptoms, associated with overlapping of symptoms in foregut disorders $(2,5-8)$.

GERD is a multi-factorial disease with a substantial prevalence in western industrial populations $(2,3,9-15)$. Therefore, if necessary, in critical, clinical situations or for research purposes, GERD should be best defined using objective testing, which provide measurable 
results on pathologic esophageal acid exposure proofing reflux and/or demonstrating visible, endoscopic damage $(12,13,14)$. Determining pathophysiologic components of GERD requires both, functional and morphologic studies to receive a complete information about anatomical and functional alterations in a given patient. Critics of a comprehensive diagnostic work-up in patients with GERD claim that this could hardly be applied in daily practice. The European Association of Endoscopic Surgery has demonstrated in its guidelines that the Montréal definition can be a basis for defining the disease, but must be expanded by objective criteria (10). Important components in the pathogenesis of GERD are the anatomy of the esophago-gastric junction (EGJ) combined with the anatomy of the hiatus and diaphragm, second the functional status of the high pressure zone in the distal esophagus, of the esophageal body and of the stomach regarding fundic accommodation, gastric emptying and gastroduodenal dysfunctions (12-14).

The purpose of this manuscript is an overview on the different pathophysiologic components of GERD, their influence as well as a certain weighing of their involvement in the disease.

\section{Anatomical Issues}

The lower esophageal sphincter (LES) represents together with the muscles and ligamentous structures of the diaphragm at the esophageal hiatus the antireflux barrier between esophagus and stomach. The functional coordination of these anatomical structures by their hormonal and neurologic regulatory mechanisms controls the complex physiologic processes of the LES and the body, which may be influenced by external factors such as psychologic components (1,3,11-14). LES and diaphragm should be seen as a functional unit, which can be best assessed by High Resolution Manometry (HRM)(14). Liebermann-Meffert has shown that specialshaped muscle fibers or clasps as well as oblique muscle bundles are responsible for the structure of the LES (16-19). Recently, this structure with an inner, circular and an outer, longitudinal muscle layer was demonstrated extremely well during transesophageal myotomy in the POEM-technique $(20,21)$. At the smaller curvature the inner, circular muscle layers transform at the transition zone in the Cardia into half-circular muscle clasps towards the proximal stomach (17). On the greater curvature, the muscle fibers below the angle of His transform into bundles of oblique fibers. Both types of muscle bundles from each side create U-shaped, half-circular muscle structures, which together form the LES. As a result, the LES consists of two structural entities and is therefore not symmetric. Branches of the vagal nerve regulate the neurologic function of the LES.

The diaphragm and its components represent the second important structure at the gastroesophageal junction $(3,12-14,16,17)$. The hiatus consists of the right and left crus, the hiatal arch as the ventral border of the hiatus and the muscular and ligamentous structures of the diaphragm around the hiatus with the phreno-esophageal ligament. The phreno-esophageal ligament secures the position of the LES within the hiatus. With this fixation of the distal esophagus, the esophageal body is kept under a certain tension within the thorax and the mediastinum, since it's longitudinal muscle tends to contract and thus tends to shorten the esophagus. In the physiologic situation a $2-3 \mathrm{~cm}$ long intraabdominal segment of the LES is secured by the phreno-esophageal ligament $(3,12,14,18,19)$.

Respiratory movements will stress these structures. Inspiration will cause a negative pressure in the thoracic pressure environment and at the same time an elevated pressure in the abdominal pressure system $(3,12,14,18$, 19). As a result, there is a permanent burden on the gastroesophageal junction and its anatomical elements, because the positive intra-abdominal pressure and respiratory based temporary negative intrathoracic pressure will tend to push the gastroesophageal junction further into the mediastinum. The latter will eventually lead to wearing out of 
these tissues. In addition, individual factors may even worsen this physiologic situation, for example a large amount of intraabdominal fat. The nutritional habits of many people in Western industrialized countries with daily overeating puts much strain on the fundus, which is the storage area of the stomach $(2,3,12)$. The repetitive enlargement of the fundus may lead to effacement of the LES. After years of strain on the LES and the diaphragm, mechanical insufficiency will develop, resulting in the development of hiatal hernia and increased reflux.

\section{Functional Issues in the Pathophysiology of GERD}

The crucial factor in GERD is an increased amount of gastric contents refluxing into the esophagus above the physiologic level $(3,12$, 14,22). This creates pathologic esophageal acid exposure (EAE) to the mucosa, which may lead to symptoms and damage $(3,12$, 14,22). The background of the failure of the antireflux barrier is discussed quite controversially, since two major directions of interpretation around the barrier function have been established $(3,12,23,24)$. Additional components may aggravate the process of refluxing such as impaired esophageal motility and/or may worsen the composition of the refluxate such additional duodeno-gastroesophageal reflux (25-28).

\section{The incompetence of the LES}

A first concept is characterized by a rather surgical and mechanical interpretation of the failure of the antireflux barrier based on manometric parameters $(1,12,13,16)$. Propagated by the „DeMeester-School“, LES-function is described by three manometric criteria, the overall length, the sphincter pressure and the sphincter position expressed as the remaining intra-abdominal length of the sphincter in the hiatal position, developed using traditional perfusion manometry $(1,12,16)$. In the physiologic situation, the high pressure zone has a length of 3 to $5 \mathrm{~cm}$ and an average pressure of around $14 \mathrm{mmHg}(1,12)$. The high pressure zone creates a sufficient and effective pressure environment over a certain length within the distal esophagus to maintain enough resistance against gastric pressure and prevent excessive acid reflux. In this concept, it is evident that the shorter the sphincter is, the higher the pressure must be within the high pressure zone to maintain a sufficient closure for prevention of reflux $(1,12)$. The LES is supported by the external, mechanical pressure of the diaphragm and the intra-abdominal pressure, of which the intra-abdominal segment of the distal esophagus is exposed causing additional compression. The longer the intra-abdominal esophageal segment is, the larger the compression area is exposed, and the more the intraabdominal pressure can support the LES in keeping reflux in a physiologic level.

A vast amount of clinical evidence has shown that these findings have a serious clinical relevance, despite the fact that these findings were generated with the limitations of perfusion manometry $(1,12,13,16,22,25)$. A major finding has been in GERD that the more advanced this disease is associated with complications such as esophagitis, ulcerations and Barrett's esophagus, the more frequent an incompetent LES is present in these patients (12,28-31). These manometric criteria of mechanical incompetence of the LES are important in the characterization of severe and progressive GERD $(1,12,16,22,30)$. Today, these findings are strongly supported by HRM using EGJ-assessment, which confirm the important role of mechanical pressure, length and position of the EGJ with regards to the diaphragm in their antireflux barrier function $(3,14,22,32,33)$.

The concept of a mechanical and functional antireflux-barrier, composed by LES and diaphragm and its weakening and shortening allowing for increased acid reflux is supported by another consideration and findings $(3,12,17,18)$. There is evidence that during and shortly after a meal the acid secretion is stimulated by several mechanisms and newly secreted acid collects in the subcardial region creating an ,acid-pocket“ $(34,35)$. This acid-pocket is directly located below the LES, 
being under strain by shortening through fundic accommodation. Thus, reflux can occur easily after large meals.

\section{The transient lower esophageal sphincter relaxations (TLESR's)}

The second concept of the antireflux barrier at the EGJ, created and propagated by Dent and Dodds, describes a spontaneous opening of the LES as the most important mechanism for the development of gastroesophageal reflux $(3,14$, 23,24). This occurs in healthy persons and also in patients with GERD and was considered a physiologic mechanism to evacuate ingested air from the gastric lumen (23,24,36-39). However, if the LES is open during such relaxations, acid reflux can occur. Transient lower esophageal sphincter relaxations (TLESR's) develop without previous swallowing, and may be increased in pathologic reflux. Usually, LESrelaxations are triggered in the process of swallowing. In TLESR's a vagal reflex is caused by stimulation at the cardia and by fundic distension (23,24,36-39). This signal reaches via afferent vagal lines the central nervous system and further causes an inhibition of the LES and diaphragm, leading to a TLESR (23,24,36-39). The relaxation develops with a pressure drop of $>1 \mathrm{mmHg} / \mathrm{sec}$ and continues for approximately $10 \mathrm{sec}(23,24,36$, 37). TLESR's were detected and recorded by a sleeve-manometry catheter inserted in the high pressure zone $(23,24)$. The sleeve catheter is able to characterize the intraluminal and integral pressure changes over the complete length of the high pressure zone. It must be emphasized that these TLESR's occur without previous swallowing and the opening of the sphincter will allow for reflux of gastric contents into the esophagus.

There has been over years a controversial discussion between gastroenterologists and surgeons about the interpretation of this phenomenon $(12,18,23,24)$. A main criticism of this concept has been based on the fact that studies have shown that TLESR's are not necessarily increased in its frequency between individuals without reflux problems and those with reflux problems, which raises the question whether there is a connection. TLESR's are especially increased in patients with GERD in the postprandial phase $(23,24$, 36-39). In contrast, in patients with progressive and advanced GERD, TLESR's may not necessarily be increased (36-39). Since physiologic LES-function depends on its intraabdominal segment, both in pressure and intraabdominal length, a spontaneous shor-tening of the sphincter in the postprandial phase will create a temporary incompetency, leading to a temporary spontaneous opening of the sphincter. The latter could fully explain the manometric observations of a TLESR in the postprandial phase $(12,18,22,23,24,36-39)$.

In a recent study, it could be shown that these two manometric approaches do not necessarily create a conflict in interpretation (40). The latter analysis shows a relationship between a mechanically incompetent LES and an increased number of reflux-associated TLESR's, suggesting that the two mechanisms are not mutually exclusive, but may be instead different measurements of the same condition - a functionally and mechanically defective LES (40).

With the introduction of High Resolution Manometry a better and more precise evaluation, the manometric assessment and interpretation of the EGJ and diaphragm has been improved substantially and allows for both, functional and mechanical features due to the large amount of assessment points $(32,33)$.

\section{Impaired esophageal motility}

Impaired esophageal motility (IEM) can delay esophageal clearance and has been investigated in GERD-patients (3-7). The prevalence of IEM in these patients is reported between $10-50 \%$ (1-8,41-43). In a previous study, our group found $14 \%$ of GERD patients to have IEM together with other components (41). IEM as an isolated pathophysiologic defect was found in only $2 \%$ (41). In another study, we documented IEM in $8.8 \%$ of the GERD study population, indicating that the majority of GERD-patients do not develop a severe, detectable IEM (13).

More recent studies concerning the ability 
of the esophagus to maintain a sufficient clearance function shows that the post-reflux swallowing-induced peristaltic wave (PSPW) may be very important in emptying the esophageal lumen from potentially damaging refluxate (44-46). The new metric characterizes the peristaltic esophageal function and its potential to reflect clearance. This can be determined as a new parameter of esophageal function (44-48).

\section{Duodeno-gastro-esophageal reflux}

Duodenogastric reflux is a physiologic phenomenon $(1,3,12,13,26,27)$. As a consequence, it is no surprise that in reflux patients, duodenal contents can reach the esophageal lumen (1,3, 12,13,25-29). Usually, together with the acid refluxate, duodenal and enteric contents can reflux into the esophagus. Duodenal refluxate can be quite harmful to the esophageal mucosa $(12,13,25-30)$. Studies of patients diagnosed with Barrett's esophagus indicated that the refluxate is composed of duodenal contents, highlighting both the presence and effect of DGER $(12,13,25-30)$. We investigated this subset of subjects with the Bilitec ${ }^{\mathrm{TM}}$ bilirubin monitoring device. Our findings support the contribution of DGER to the pathophysiology of GERD, particularly in Barrett patients $(12,13$, 25-30). This implication may play a role in the progression of GERD and Barrett's esophagus $(25,26,28-30)$.

\section{Gastro-duodenal dysfunctions}

Gastric and duodenal motility disorders may play an accompanying role in GERD $(3,12,13$, $19,22,25,29,30,49,50)$. This occurs in the primary situation less common, and usually presents as delayed gastric emptying (DGE) causing stasis of gastric contents, ultimately leading to back-up-reflux. In the literature, DGE is reported to be involved in GERD in5-33 \% $(3,12,13,19,22,25,49,50)$. In a recent study, we detected DGE in only $6.8 \%$ of our GERD-patients (13).

\section{The Role of Obesity}

As explained above, increased intraabdominal fat may elevate intraabdominal pressure and this may cause increased gastroesophageal reflux (12). Obesity, defined as a body mass index greater than or equal to 30 is associated with an increased prevalence of GERD as compared to the non-obese patient population (51-54). A variety of explanations for increased frequency of GERD with increasing body weight have been proposed (3,4,5,51-54). Obesity can cause increased esophageal acid exposure (53). Studies showed a statistically significant inverse relationship between BMI and LES pressure (51-54). We documented recently in a large GERD-patient cohort a mean BMI of 27 , with only $15.8 \%$ of patients falling in the category of BMI $>30$. This is a rather low mean BMI-level for a cohort of GERD-patients, which may explain the apparent lesser contribution of obesity to GERD in our patients (13).

\section{Histopathologic and Mucosal Considerations}

For many years, the alterations at the esophageal mucosal level were insufficiently followed and assessed $(1,2,3,12)$. Few investigators were able to study these changes $(55,56)$. Acid and other agents in the refluxate can harm the esophageal squamous epithelium $(1,3,12,26,29,30,57-59)$. There is some evidence that even more severe damage can occur by the mixture of acid and duodenal contents in the esophageal mucosa, which can lead to intestinal metaplasia and Barrett's esophagus $(1,3,12,26,29,30,57-59)$. Chandrasoma et al. have investigated the histopathologic changes in the cardia from the normal physiologic setting to more specific changes in patients with incompetent LES and GERD $(57,58)$. As mentioned above, a new metric of MNBI (mean nocturnal baseline impedance) can be a marker for mucosal integrity in the future and may pave the way for a more pragmatic approach to assessment of mucosal status (44-47).

In the physiologic situation, squamous epithelium is directly connected at the transition zone to the gastric epithelium (gastric oxyntic mucosa) $(12,27,57-60)$. In the process of strain on the EGJ, increased EAE 
will damage the squamous epithelium. These have an anatomical component and a histopathologic component. The anatomic component is represented by the shortening of the LES due to strain by effacement. The histopathologic component is a change from squamous epithelium in the distal esophagus to a columnar lined epithelium also called „carditis“ (57-59). During this process, the very distal part of the esophagus and LES is dilated and the former squamous cell epithelium is taken over by cardiac mucosa and carditis. These processes may influence the functional deterioration.

\section{Pathophysiologic Overview}

Pathophysiology of GERD is multifactorial and influenced by a number of different components that can be involved in varying severity $(1-8,12,13,14,22,30)$. These components are recognized in several guidelines and this knowledge is by now integrated in the diagnostic and therapeutic management of GERD in centers $(2,3,10,14)$. Table 1 demonstrates an overview on the involved pathophysiologic components in several large series and reviews $(3,9,11,13,25,30,41,61)$. The most important components are anatomical changes at the EGJ and functional alterations in the esophagus. The incompetence of the LES and EGJ has a major involvement of more than $80 \%$ of patients $(3,12,13)$. Furthermore, the presence of a hiatal hernia as the most severe anatomical change is also involved in more than $80 \%$ of patients with severe disease $(3,12,13)$. Other contributing factors range at lower incidences (Table 1).

It is very important to understand the disease and its possible progress, which should be stopped by optimal therapeutic management. The onset of the disease can occur often by mechanical weakening of the esophagogastric junction, by transient sphincter relaxations or temporary shortening of the LES $(2,3,12,13)$. More severe alterations can be caused by a primary shortening of the esophagus (12). Any weakness of the connective tissue with the tendency of hernia development may also have its influence on the structure of the hiatus and the dislocation of the gastroesophageal junction $(3-8,12)$. These primary changes can of course be worsened by the described mechanisms of excessive eating habits in Western societies. Mechanical strain by overeating, development of obesity and increased intra-abdominal fat will cause intra-abdominal pressure increase, which both will weaken the stable position of the esophagus in the hiatus. Thus, it is not surprising that GERD has a high prevalence in Western societies with their specific eating habits.

The natural course of the disease is

Table 1. Overview on the presence (percentage) of pathophysiologic factors in GERD in literature

\begin{tabular}{|c|c|c|c|c|c|c|c|}
\hline Author / year & LES & TLESR & HH & DGER & DGE & IEM & Obesity \\
\hline Skinner, 1970 & 82 & - & 65 & & & 21 & \\
\hline Stein, 1992 & 91 & - & 82 & - & 33 & 16 & 15 \\
\hline Fuchs, 1995 & 87 & - & 80 & 6 & 5 & 14 & - \\
\hline Boeckxstaens, 2007 & 90 & 33 & 75 & - & $10-33$ & $25-48$ & - \\
\hline $\begin{array}{l}\text { Lord/ } 2009 \\
\text { ERD +BE } \\
\text { NERD + mild ERD }\end{array}$ & $\begin{array}{l}80 \\
57\end{array}$ & - & $\begin{array}{l}85 \\
49\end{array}$ & $\begin{array}{c}\text { BE } 79 \\
\text { ERD } 50 \\
\text { NERD } 52\end{array}$ & & & \\
\hline Herbella, 2010 & high & 40 & 54 & - & - & $\begin{array}{c}40-50 \\
\text { Severe } 20\end{array}$ & - \\
\hline Herregods, 2015 & high & $\begin{array}{c}\text { Association } \\
\text { with acid }\end{array}$ & - & 12 & Related & OR: 1,87 & 31 \\
\hline Fuchs, 2020 & 88 & $\begin{array}{l}\text { Correlation between } \\
\text { TLESR's and } \\
\text { incomp LES }\end{array}$ & 95 & 55 & 7,9 & 8,8 & 25,6 \\
\hline
\end{tabular}


determined by the chronic character and the progressive development in some of the involved patients $(3,12,22)$. Studies with large cohorts of patients have shown that most patients stay within a certain level of severity of the disease over decades $(59,60)$. This may characterize the benign nature of this functional disorder, however, there exists a cohort of patients with more severe disease and tendency towards progression $(22,30,31,59,60,62)$. The latter can not only ruin the quality of life of these patients, but also can progress to complicated forms of the disease and in a minority even to cancer $(22,30,31,60)$.

This enlightens the importance of early detection of these patients with more progressive disease in order provide them with an improved attention and earlier management of diagnosis and therapy.

All known pathophysiologic components of GERD can be investigated currently by diagnostic assessment, detecting a LESincompetence or an increase in transient relaxations, detecting a hiatal hernia with increasing size, detecting increasing exposure to gastric contents in addition to other possible functional associated disorders such as an insufficient esophageal motility and or a delayed gastric emptying, which all can aggravate the disease and the patient's status.

\section{Conflict of Interest}

The authors declare no conflicts of interests.

\section{References}

1. DeMeester TR. Definition, detection and pathophysiology of gastroesophageal reflux disease. In: International trends in general thoracic surgery, vol.3, editors: DeMeester TR, Matthews HR. Benign esophageal disease. St. Louis: Mosby; 1987. p. 99-127.

2. Vakil N, van Zanten SV, Kahrilas PJ, Dent J, Jones R, and the global consensus Group. The Montreal definition and classification of gastroesophageal reflux disease: a global evidence-based consensus. Am J Gastroenterol. 2006;101(8):1900-20; quiz 1943.

3. Boeckxstaens GEE. Review: the pathophysiology of gastro-esophageal reflux disease. Aliment Pharmacol Ther. 2007;26(2):149-60.

4. Kardos P, Dinh QT, Fuchs KH, Gillissen A, Klimek L, Koehler M, et al. German Respiratory Society guidelines for diagnosis and treatment of adults suffering from acute, subacute and chronic cough. Respir Med. 2020; 170:105939.

5. Klauser AG, Schindlbeck NE, Müller-Lissner SA. Symptoms in gastro- esophageal reflux disease. Lancet. 1990;335(8683):205-8.

6. Costantini M, Crookes PF, Bremner RM, Hoeft SF, Ehsan A, Peters JH, et al. Value of physiologic assessment of foregut symptoms in a surgical practice. Surgery. 1993;114(4):780-6; discussion 786-7.

7. Fuchs KH, Musial F, Ulbricht F, Breithaupt W, Reinisch A, Schulz T, et al. Foregut symptoms, somatoform tendencies, and the selection of patients for antireflux surgery. Dis Esophagus. 2017;30(7):1-10.

8. Broderick R, Fuchs KH, Breithaupt W, Varga G, Schulz T, Babic B, et al. Clinical Presentation of Gastroesophageal Reflux Disease: A Prospective Study on Symptom Diversity and Modification of Questionnaire Application. Dig Dis. 2020;38(3):188-195. Epub 2019 Sep 12.

9. Herbella FA, Patti MG. Gastroesophageal reflux disease: from pathophysiology to treatment. World J Gastroenterol. 2010 Aug 14;16(30):3745-9.

10. Fuchs KH, Babic B, Breithaupt W, Dallemagne B, Fingerhut A, Furnee E, et al. EAES recommendations for the management of gastroesophageal reflux disease. Surg Endosc. 2014;28(6):1753-73.

11. Herregods TVK, Bredenoord AJ, Smout AJPM. Pathophysiology of gastroesophageal reflux disease: new understanding in a new era. Neurogastroenterol Motil. 2015;27(9):1202-13.

12. DeMeester TR. Etiology and Natural History of Gastroesophageal Reflux Disease and Predictors of progressive Disease. In: Shackelford's Surgery of the Alimentary Tract, editors CJ Yeo, SR DeMeester, DW Mc Fadden, $8^{\text {th }}$ edition. Philadelphia: Elsevier; 2019. p. 204-220.

13. Fuchs KH, Lee AM, Breithaupt W, Varga G, Babic B, Horgan S. Pathophysiology of GERD - which factors are important? Transl Gastroenterol Hepatol 2020; doi.org/10.21037/tgh.2020.02.12.

14. Gyawali CP, Kahrilas PJ, Savarino E, Zerbib F, Mion F, Smout AJPM, et al. Modern diagnosis of GERD: the Lyon Consensus. Gut. 2018; 67(7):1351-1362.

15. Broderick R, Fuchs KH, Breithaupt W, Varga G, Schulz T, Babic B, et al. Clinical Presentation of Gastroesophageal Reflux Disease: A Prospective Study on Symptom Diversity and Modification of Questionnaire Application. Dig Dis. 2020;38(3):188-195. Epub 2019 Sep 12.

16. Zaninotto G, DeMeester TR, Schwizer W, Johansson KE, Cheng SC. The lower esophageal sphincter in health and disease. Am J Surg. 1988;155(1): 104-11.

17. Liebermann-Meffert D, Duranceau A, Anatomy and embryology of the esophagus. In: Orringer MB, Zuidema GD (eds) Shackelford`s surgery of the alimentary tract, vol 1, The esophagus, $4^{\text {th }}$ edition. Philadephia London Toronto Montreal Sydney Tokyo: Saunders; 1996. p. 3-38.

18. Ayazi S, Tamhankar A, DeMeester SR, Zehetner J, Wu C, Lipham JC, et al. The impact of gastric distension on the lower esophageal sphincter and its exposure to acid gastric juice. Ann Surg. 2010;252(1):57-62.

19. Fuchs KH, Babic B, Fuchs HF. Esophageal Sphincters in Health and Disease. in Shackelford's Surgery of the Alimentary Tract, eds CJ Yeo, SR DeMeester, DW Mc Fadden, 8th edition. Philadelphia: Elsevier; 2019. p. 2-10.

20. Inoue H, Minami H, Kobayashi $Y$, Sato $Y$, Kaga M, Suzuki M, et al. Peroral endoscopic myotomy (POEM) for esophageal achalasia. Endoscopy. 2010;42(4):265-71.

21. von Renteln D, Fuchs KH, Fockens P, Bauerfeind P, Vassiliou M, Breithaupt W, et al. Peroral endoscopic myotomy for the treatment of achalasia: an international prospective multicenter study. Gastroenterology. 2013; 145(2):309-11.e1-3

22. Fuchs KH, DeMeester TR, Otte F, Broderick RC, Breithaupt W, Varga G, et al. Severity of GERD and disease progression. Dis Esophagus. 2021 Feb 11:doab006.

23. Dent J, Holloway RH, Toouli J, Dodds WJ. Mechanisms of lower oesophageal sphincter incompetence in patients with symptomatic gastrooesophageal reflux. Gut. 1988;29(8):1020-8.

24. Mittal RK, Holloway RH, Penagini R, Blackshaw A, Dent J. Transient lower esophageal sphincter relaxations. Gastroenterology. 1995;109(2):601-10.

25. Stein HJ, Barlow AP, DeMeester TR, Hinder RA. Complications of gastroesophageal reflux disease. Role of the lower esophageal sphincter, esophageal acid and acid/alkaline exposure, and duodenogastric reflux. Ann Surg. 1992;216(1):35-43.

26. Fein M, Ireland AP, Ritter MP, Peters JH, Hagen JA, Bremner CG, et al. Duodenogastric reflux potentiates the injurious effects of gastroesophageal 
reflux. J Gastrointest Surg. 1997:1(1):27-32; discussion 33.

27. Fuchs KH, Maroske J, Fein M, Tigges H, Ritter MP, Heimbucher J, et al. Variability in the composition of physiologic duodenogastric reflux. J Gastrointest Surg. 1999;3(4):389-95; discussion 395-6.

28. Fein M, Maroske J, Fuchs KH. Importance of duodenogastric reflux in gastro-oesophageal reflux disease. Br J Surg. 2006;93(12):1475-82.

29. Oberg S, Ritter MP, Crookes PF, Fein M, Mason RJ, Gadensytätter M, et al. Gastroesophageal reflux disease and mucosal injury with emphasis on short-segment Barrett's esophagus and duodenogastroesophageal reflux. J Gastrointest Surg. 1998;2(6):547-53; discussion 553-4.

30. Lord RVN, DeMeester SR, Peters JH, Hagen JA, Elyssnia D, Sheth CT, et al. Hiatal hernia, lower esophageal sphincter incompetence, and effectiveness of Nissen fundoplication in the spectrum of gastroesophageal reflux disease. J Gastrointest Surg. 2009;13(4):602-10. Epub 2008 Dec 3.

31. Labenz J, Chandrasoma PT, Knapp LJ, DeMeester TR. Proposed approach to the challenging management of progressive gastroesophageal reflux disease. World J Gastrointest Endosc. 2018; 10(9):175-183.

32. Kahrilas PJ, Bredenoord AJ, Fox M, Gyawali CP, Roman S, Smout AJ, et al. The Chicago Classification of esophageal motility disorders, v3.0. Neurogastroenterol Motil. 2015;27(2):160-74.

33. Roman S, Holloway R, Keller J, Herbella F, Zerbib F, Xiao Y, et al. Validation of criteria for the definition of transient lower esophageal sphincter relaxations using high-resolution manometry. Neurogastroenterol Motil. 2017;29(2).

34. Clarke AT, Wirz AA, Seenan JP, Manning JJ, Gillen D, McColl KE. Paradox of gastric cardia: it becomes more acidic following meals while the rest of stomach becomes less acidic. Gut. 2009;58(7):904-9. Epub 2008 Dec 5.

35. Beaument H, Benninck RJ, de Jong J, Boeckxstaens GE. The position of the acid pocket as a major risk factor for acidic reflux in healthy subjects and patients with GORD. Gut. 2010;59(4):441-51. Epub 2009 Aug 2.

36. Holloway RH, Kocyan P, Dent J. Provocation of transient lower esophageal sphincter relaxations by meals in patients with symptomatic gastroesophageal reflux. Dig Dis Sci. 1991;36(8):1034-9.

37. Schoeman MN, Tippett MD, Akkermans LM, Dent J, Holloway RH. Mechanisms of gastroesophageal reflux in ambulant healthy human subjects. Gastroenterology. 1995;108(1):83-91.

38. Van Herwaarden MA, Samson M, Smout AJP. Excess gastroesophageal reflux in patients with hiatal hernia is caused by mechanisms other than transient LES relaxations. Gastroenterology. 2000;119(6):1439-46.

39. Trudgill NJ, Riley SA. Transient lower esophageal sphincter relaxations are no more frequent in patients with gastroesophageal reflux disease than in asymptomatic volunteers. Am J Gastroenterol. 2001;96(9):2569-74.

40. Fuchs KH, Freys SM, DeMeester TR. Transient Lower Esophageal Sphincter Relaxations and mechanical Incompetence of the Lower Esophageal Sphincter - Is there a relationship? J Surg Res 2020;3(3):317-328.

41. Fuchs KH, Freys SM, Heimbucher J, Fein M, Thiede A. Pathophysiologic spectrum in patients with gastroesophageal reflux disease in a surgical $\mathrm{Gl}$ function laboratory. Dis Esophagus 1995;8:211-217.

42. Diener U, Patti MG, Molena D, Fisichella PM, Way LW. Esophageal dysmotility and gastroesophageal reflux disease. J Gastrointest Surg. 2001; 5(3):260-5.

43. Kahrilas PJ. Esophageal motor disorders in terms of high-resolution esophageal pressure topography: what has changed? Am J Gastroenterol. 2010;105(5):981-7.

44. Frazzoni M, Savarino E, de Bortoli N, Martinucci I, Furnari M, Frazzoni L, et al. Analyses of the Post-reflux Swallow-induced Peristaltic Wave Index and Nocturnal Baseline Impedance Parameters Increase the Diagnostic Yield of Impedance-pH Monitoring of Patients With Reflux Disease. Clin Gastroenterol Hepatol. 2016;14(1):40-6.
45. Frazzoni L, Frazzoni M, de Bortoli N, Tolone S, Furnari M, Martinucci I, et al. Postreflux swallow-induced peristaltic wave index and nocturnal baseline impedance can link PPI-responsive heartburn to reflux better than acid exposure time. Neurogastroenterol Motil. 2017;29(11).

46. Ribolsi M, Frazzoni M, De Bortoli N, Tolone S, Arsiè E, Mariani L, et al. Reflux characteristics triggering post-reflux swallow-induced peristaltic wave (PSPW) in patients with GERD symptoms. Neurogastroenterol Motil. 2021 May 29:e14183.

47. Rengarajan A, Savarino E, Della Coletta M, Ghisa M, Patel A, Gyawali CP. Mean Nocturnal Baseline Impedance Correlates With Symptom Outcome When Acid Exposure Time Is Inconclusive on Esophageal Reflux Monitoring. Clin Gastroenterol Hepatol. 2020;18(3):589-595.

48. Yadlapati R, Kahrilas PJ, Fox MR, Bredenoord AJ, Prakash Gyawali C, Roman $S$, et al. Esophageal motility disorders on high-resolution manometry: Chicago classification version 4.0@. Neurogastroenterol Motil. 2021;33(1):e14058.

49. Bredenoord AJ, Chial HJ, Camilleri M, Mullan BP, Murray JA. Gastric accomodation and emptying in evaluation of patients with upper gastrointestinal symptoms. Clin Gastroenterol Hepatol. 2003;1(4):264-72.

50. Penagini $R$, Bravi I. The role of delayed gastric emptying and impaired oesophageal body motility. Best Pract Res Clin Gastroenterol. 2010; 24(6):831-45.

51. El-Serag HB, Graham DY, Satia JA, Rabeneck L. Obesity is an independent risk factor for GERD symptoms and erosive esophagitis. Am J Gastroenterol. 2005;100(6):1243-50

52. Jacobson BC, Somers SC, Fuchs CS, Kelly CP, Camargo CA. Body-mass index and symptoms of gastroesophageal reflux in women. N Engl J Med. 2006;354(22):2340-8

53. Ayazi S, Hagen JA, Chan LS, DeMeester SR, Lin MW, Ayazi A, et al. Obesity and gastroesophageal reflux: quantifying the association between body mass index, esophageal acid exposure, and lower esophageal sphincter status in a large series of patients with reflux symptoms. J Gastrointest Surg. 2009;13(8):1440-7.

54. Nadaleto BF, Herbella FA, Patti MG. Gastroesophageal reflux disease in the obese: Pathophysiology and treatment. Surgery. 2016;159(2):475-86.

55. Orlando RC, Bryson JC, Powell DW. Mechanisms of $\mathrm{H}_{+}$injury in rabbit esophageal epithelium. Am J Physiol. 1984;246(6 Pt 1):G718-24.

56. Orlando RC. Esophageal epithelial defenses against acid injury. Am J Gastroenterol. 1994;89(8 Suppl):S48-52.

57. Oberg S, Peters JH, DeMeester TR, Chandrasoma P, Hagen JA, Ireland Ap, et al. Inflammation and specialized intestinal metaplasia of cardiac mucosa is a manifestation of Gastroesophageal reflux disease. Ann Surg. 1997; 226(4):522-30; discussion 530-2.

58. Oberg S, Peters JH, DeMeester TR, Lord RV, Johansson J DeMeester SR, et al. Determinants of intestinal metaplasia within the columnar-lined esophagus. Arch Surg. 2000;135(6):651-5; discussion 655-6.

59. Chandrasoma P, Lokuhetty DM, DeMeester TR, Bremner CG, Peters JH, Oberg S, et al. Definition of histopathologic changes in GERD. Am J Surg Pathol. 2000;24(3):344-51.

60. Leodolter $A$, Nocon $M$, Vieth $M$, Lind $T$, Jaspersen $D$, Richter $K$, et al. Progression of specialized intestinal metaplasia at the cardia to macroscopically evident Barrett's esophagus: an entity of concern in the ProGERD study. Scand J Gastroenterol. 2012;47(12):1429-35.

61. Skinner DB, Booth DJ. Assessment of distal esophageal function in patients with hiatal hernia and-or gastroesophageal reflux. Ann Surg. 1970;172(4): 627-37.

62. Malfertheiner $\mathrm{P}$, Nocon M, Vieth M, Stolte M, Jaspersen D, Koelz HR, et al. Evolution of gastro-oesophageal reflux disease over 5 years under routine medical care - the ProGERD study. Aliment Pharmacol Ther. 2012;35(1): 154-64. Epub 2011 Nov 9. 